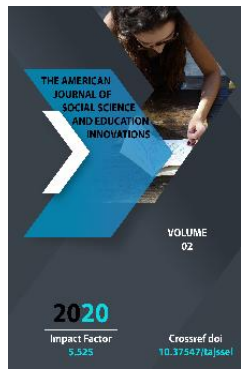

Copyright: Original content from this work may be used under the terms of the creative commons attributes 4.0 licence.

\section{Innovative Geographical Education - A Factor For Effective Formation Of Geographical Culture}

\author{
Avazov Sherimmat \\ Tashkent State Pedagogical University Professor, Candidate Of Pedagogical Sciences, \\ Uzbekistan \\ Saydamatov Farkhod Rajabovich \\ Tashkent State Pedagogical University Great Teacher Tashkent, Uzbekistan
}

\title{
ABSTRACT
}

This article reveals the most common innovative technologies in geography education, the relevance of innovative geographical education, the main objectives of innovative geographical education, the tasks, basic principles (principles) of innovative geographical education and the factors of their effective formation of geographical culture. The teacher is taught to understand innovative geographical education as a method of forming a geocologically cultured (competent) student / student personality. Enlightenment (pedagogical) innovation is mainly covered by the following concepts - innovation, educational innovation, innovation, innovation, innovation process, innovation activity, pedagogical innovation, pedagogical innovation, pedagogical innovation process, pedagogical innovation activity.

\section{KEYWORDS}

Innovation, geography, education, culture, factor, form, student, technology

\section{INTRODUCTION}

Innovative technologies in geography education allow to regulate the educational process, to direct it in the right direction. Readers are often stunned and confused by new perspectives on geography and unfamiliar facts, and react negatively to such changes. The stereotypes or monotony that are mass-formed in the minds of geography teachers, affecting their normal pedagogical activities, often lead to painful situations, i.e., 
to the renewal of forms of geography education. The reason why a teacher is reluctant to embrace innovations in modern geography education is because it blocks vital needs for convenience, safety, and selfexpression.

\section{THE MAIN RESULTS AND FINDINGS}

Innovative behavior (behavior) of a geography teacher does not mean adaptation to the educational process, that is, adaptation, but its specific professional formation, selfprofessional development. The teacher must understand innovative geographical education as a method of forming a geo-ecological culture (competent) student personality. The teacher should not be recommended "ready didactic (methodical) templates", because it is important for him to constantly improve his geographical and methodological intellectual level. A teacher who is free from psychological barriers and any "dependencies" can become a full participant in innovative change.

One of the tasks of a modern secondary, secondary special and higher school is to reveal the inner potential of all participants in the pedagogical process, to give them the opportunity to fully demonstrate their creative abilities. These tasks cannot be solved without ensuring the variability, ie the variability of the enlightenment (educational) regions. Due to variability, different innovative types or types of educational institutions emerge, which require a deep scientific and methodological understanding.

Today, innovation is a field of knowledge that studies the formation of innovations, their dissemination, as well as methods of developing new solutions or the methodology of innovative activity, its organization, and has become the most relevant area not only in economics but also in education. From this point of view, educational innovation is a field of pedagogical knowledge or science that studies the nature, origin and development of educational innovations in relation to educational subjects, the subject of study of which is pedagogical innovation and innovation, pedagogical innovation. process and activity. Therefore, educational innovation works mainly with the following concepts [1]:

Innovation (Latin novatio - renewal, change) an innovation based on a new idea or new scientific discovery (new procedure, method, image, habit, etc.);

Innovation (English innovation - update, renewal) - the result of the practical mastering of an innovation or innovation introduced into practice in order to increase the efficiency of processes or ensure the improvement of product (service) quality;

Innovation process - a sequence of stages of creation and use of innovations;

Innovative activity - a set of activities, including the search, selection and development of innovative ideas based on them, the introduction of innovations and their dissemination (reproduction).

The application of these concepts to the theory and practice of pedagogy has led to the formation of the following specific pedagogical concepts:

Pedagogical innovation - improvement of the pedagogical experience developing in the order of tradition (gradual ascent);

pedagogical innovation - pedagogical innovation, ie progressive changes that introduce sustainable elements (innovations) in the educational environment that improve the character of the education system and some of its components, in other words, provide changes (exchange) of existing 
teaching methods and technologies in the educational process. introduction of

Pedagogical innovation process - a sequence of stages of creation and use of pedagogical innovations, in other words, the process of continuous development of education through the creation, mastering and application of pedagogical innovations;

Pedagogical innovative activity is a set of measures aimed at ensuring the normal pedagogical process itself, as well as the pedagogical innovation process at some level of education and upbringing.

It can be said that pedagogical innovation is an internal but possible change, pedagogical innovation is a real change.

Widespread innovative technologies in geography education:

1) game technologies;

2) design technologies;

3) problem-based learning technology;

4) differentiated educational technology;

5) technology of educational and research activities.

The relevance of innovative geographical education is explained by the following:

1) conformity of geographical education to the concept of humanization;

2) elimination of formalism and authoritarian style in the system of geographical education;

3) introduction of person-centered geographical education;

4) creation of conditions for the discovery of the geographical creative potential of the student;

5) conformity of independent geographical creative activity to socio-cultural and ecological needs of modern society.
The main objectives of innovative geographical education include:

1) the formation of a high level of geographical culture in students;

2) development of different types of geographical thinking in students;

3) development of geographical, intellectual, communicative, linguistic and creative abilities of students;

4) the formation of skills that affect the geographical educational activities of students and the transition to a level of productive creativity;

5) formation of quality geographical knowledge, skills, competencies and competencies in students.

These general objectives define the following tasks of innovative geographical education:

1) creation of the most favorable conditions for the process of geographical education;

2) creating and establishing an environment of cooperation between students and a teacher of geography;

3) development of continuous positive motivation of students in geography education;

4) involvement of students in geographical creative activity;

5) Careful selection of geographical educational materials and methods of their delivery to the student.

Innovative geographical education is based on the following technologies:

1) developmental geographical education;

2) problematic geographical education;

3) development of geographical critical thinking or thinking;

4) a differentiated approach to geographical education;

5) creating an environment (situation) of success in geography lessons. 
The main principles of innovative geographical education are:

1) the principle of creativity (aiming for creativity);

2) the principle of systematic acquisition of knowledge (acquisition of knowledge within certain systems or subsystems);

3) the principle of superiority of nontraditional forms of education;

4) the principle of demonstration.

In the field of use of innovative technologies in the teaching of geography, the following methodological methods can be effectively used: the method of basic texts; mental attack method; group discussion method; essay method; method of base terms; video film method; how to read a map; didactic game method; how to work with text; method of distribution materials; electronic board method; electronic book method; method of independent work; instruction sheet method; creative assignment method; repetition method; unconventional homework method; self-assessment method, etc.

Innovative geography education should include not only innovations in teaching methods, tools or organizational forms, but also innovations in the content of geography education. In the absence of innovations in the content of geography education, innovations in teaching methods, tools, organizational forms or technologies result in geographical education, ie a geographically cultured person with geographical knowledge, practical skills, competencies and competencies, as well as real needs for today's geographical education. unsatisfactory.

A comparative comparison and analysis of the content of geography education in general secondary, secondary special and higher education institutions with the practice of developed countries shows that the content of existing geography programs is not lower than modern requirements, but some shortcomings in the program structure, geoecology stands out. In particular, the system of geographical knowledge in some curricula, methods of scientific geographical study of natural, economic and social geographical objects, events and processes, methods of practical application of geographical knowledge, skills and abilities, development of students' experience of creative geographical activity. Some aspects of issues such as the formation of a responsible attitude to the environment have not been updated or included in the content of education for a number of years. After all, any geographical curriculum, regardless of the level of study (school, lyceum, college, institute, university) is a copy of the field of geographical scientific knowledge. Therefore, they should, as far as possible, cover the basics of theoretical knowledge in the field of integrated geography or its relevant scientific directions, acquaint students with the following basic geographical laws, doctrines, theories, concepts and scientific hypotheses:

I. Geographical laws and regulations:

1. The law of integrity of the geographical crust.

2. The law of uniformity of the geographical crust.

3. The law of zonal distribution of the geographical crust.

II. Geographical teachings:

1. General teachings:

The doctrine of the use of nature.

The doctrine of the world's oceans.

Doctrine of soils.

Theory of the biosphere.

1.5. The doctrine of the ecosphere. 
The doctrine of the noosphere.

1.7.The doctrine of evolution.

2. Natural geographical teachings:

2.1. The doctrine of the geographical crust.

The doctrine of distribution by geographical zones.

Doctrine of geographical landscape.

Doctrine of natural-territorial complexes.

3. Socio-economic geographical doctrines:

Theory of economic geography.

3.2. Doctrine of geographical (territorial) division of labor.

3.3. Doctrine of territorial-industrial complex.

\section{Cartographic teachings:}

The doctrine of the map.

5. Doctrines related to border sciences:

Doctrine of natural foci of disease.

Theory of geobiocenosis.

Theory of landscape geochemistry.

III. Geographical scientific theories:

1. General theories:

1.1. Theory of forecasting.

Theory of sustainable development.

1.3.The theory of geographical determinism.

1.4. Theory of regional planning.

2. General geographical theories:

Theory of regional development.

2.2.Theory of geographical assessment.
2.3.Theory of natural and man-made hazards.

3. Natural geographical theories:

3.1. Theory of natural geographical areas.

3.2.Theory of lithosphere foci.

4. Economic geographical theories:

Theory of placement of productive forces.

Theory of economic zoning.

4.3.The theory of the world economy.

Theory of the territorial structure of the economy and location.

4.5.The theory of urbanization.

5. Theories related to border sciences:

Theory of demographic change.

5.2. Theory of ethnogenesis.

IV. Geographical scientific concepts:

1. The concept of geotechnical systems.

2. The concept of environmental monitoring.

3. The concept of geographical expertise.

4. The concept of a polarized landscape.

5. The concept of stability and variability of geosystems.

6. The concept of territorial-recreational systems.

7. The concept of "environmental demand".

8. The concept of geopolitics.

9. The concept of historical and cultural areas.

V. Geographical scientific assumptions:

1.Scientific hypothesis of cosmogony.Vale 


\section{Scientific hypothesis "Continental drift".}

3. Scientific hypothesis "Effect of vapor gases".

VI. Directions in the content of geographical education:

1. The direction of humanism is to look at nature as the environment in which humanity came into being and lived.

2. Social orientation - the recognition of the role of the individual in the life of nature and society.

3. Ecological direction - the formation of ecological culture.

4. Economic direction - the formation of economic culture.

The problem is that no one is scientifically substantiating in which curricula any of the above-mentioned geographical knowledge should be basic and which should be auxiliary. For example, one of the three main competencies defined in the current geography curriculum for secondary schools is the acquisition of comprehensive geographical knowledge, skills and competencies, as well as the new qualification requirements for graduates of general secondary education in geography [2]. and despite the requirement to form the competence of ecological culture, the curriculum of the pedagogical university, prepared by geography teachers, includes only 16 hours of lectures and 22 hours of practical training for the course "Ecology and Nature Protection" (no seminars and laboratory classes). , "Biogeography" is not studied at all.

Now let's analyze.

1. The course "Ecology and Nature Protection" focuses on the geographical basis of nature protection, the interaction between man and nature, natural resources and their types, natural conditions and their use, geoecological factors, environmental pollution. studied in a narrow range. Naturally, the question arises: the above-mentioned general doctrines on the biosphere, noosphere, ecosphere and nature management, geographical landscape, as well as doctrines related to natural-hearth diseases, geobiocenosis, border geochemistry, sustainable development general geographical theories such as general brain, natural and man-made hazard theory, environmental monitoring, geographical expertise, geosystem stability and variability, geographical scientific concepts such as environmental demand, scientific hypotheses such as the effects of vapor gases, the formation of ecological culture in the context of geographical education If the scientific basis is not studied in the course "Ecology and Nature Protection" or "Biogeography", in which general or specialty disciplines are studied? It is impossible to talk about geographical culture without understanding, systematic knowledge of these issues, which are among the basic geographical doctrines, theories, concepts, scientific hypotheses. Therefore, only through innovative geographical education can these problems be solved.

2. In the courses "Ecology and Nature Protection" and "Biogeography" graduates who do not have sufficient knowledge, skills and abilities, as a result of which the geographical culture is low or insufficient - the future geography teacher to protect the nature of nature defined in state regulations and can adequately shape the competence of shaping ecological culture? Or can such a category of teachers develop a geo-ecologically 
conscious, thoughtful and cultured student who will be able to overcome the socioecological crisis associated with the drying up of the Aral Sea and climate change in Uzbekistan, or improve the environment? Similar questions related to the nature of our country and the future of our nation are related to the content of geography education, and can be resolved positively only through the implementation of innovations in the content of education.

3. In accordance with the Declaration of Ethical Principles Concerning the Deterioration of the Environmental Situation in the World and Some Regions and Climate Change, environmental ethics and environmental values are studied as a separate course (module) in higher education in countries such as the United States, Great Britain, Germany, Russia and Belarus. In these courses, the ethical aspects of the relationship between nature and society, man and the environment, in particular, the unique ethical principles and requirements that define the rules of human behavior in nature, as well as national, local on climate change mitigation. and the content of the system of measures at the individual level will be studied, and the relevant ethical geoecological competencies will be formed in the graduates. So why don't we have the most up-to-date, practical courses on life and the future like this? Is the socioecological situation in our country or the geo-ecological culture in our society superior to others? Did the drying up of the Aral Sea or the dire ecological situation in the Aral Sea occur spontaneously, without the human factor?

\section{CONCLUSION}

Similar issues are reflected in the content of innovative geographical education, we believe that it will be possible to successfully form a student or student with a high geographical culture.

\section{REFERENCES}

1. Zufarov Sh. Pedagogical innovation. - T .: "Science and Technology" Publishing House, 2012.

2. Resolution of the Cabinet of Ministers of the Republic of Uzbekistan dated April 6, 2017 No 187 "On approval of state educational standards of general secondary and secondary special, vocational education."

3. Environmental ethics: textbook / A.A. Sychev and others - SPb, "Eidos", 2014.

4. Educational-methodical complex on the module "Innovative development and strategies of geographical sciences". - T.: BIMM, TDPU, 2019

5. Boltabayevich, B. B., \& Shodievna, B. O. (2020). Individual Approach To The Formation Of Artistic And Creative Talents Of Students In Art Schools. The American Journal of Social Science and Education Innovations, 2(08), 637-642.

6. Baymetov, B. B., \& Sharipjonov, M. S. O. (2020). Development Of Students' Descriptive Competencies In Pencil Drawing Practice. The American Journal of Social Science and Education Innovations, 2(08), 261-267.

7. Omonov, Q., \& Karimov, N. (2020). Importance Of Ancestoral Heritage. The American Journal of Social Science and Education Innovations, 2(09), 196-202.

8. Cook, l., \& Crang, P. (1996). The world on a plate: culinary culture, displacement and geographical knowledges. Journal of material culture, 1(2), 131-153. 